\title{
Retraction Note: HMGB1: a novel protein that induced platelets active and aggregation via Toll-like receptor-4, NF-KB and cGMP dependent mechanisms
}

Xinyu Yang ${ }^{1}$, Haichao Wang ${ }^{2}$, Menmen Zhang ${ }^{3}$, Jin Liu' ${ }^{1}$, Ben Lv ${ }^{1,2}$ and Fangping Chen ${ }^{1,3^{*}}$

\section{Retraction Note: Yang et al. BMC Diagnostic Pathology (2015) 10:134 DOI 10.1186/s13000- 015-0348-3}

This article [1] is retracted at request of the Editor. After publication of this article [1] concerns were raised regarding the methodology, in particular the controls being insufficient to provide data to fully support the stated conclusions. In addition, there was inadequate documentation of the statistical methods used. Furthermore, errors in the language throughout the text and poor labeling of figures were potentially misleading to the reader. The authors have been given an opportunity to submit a corrected version. All authors agree to this retraction. Author Haichao Wang has stated that he was not involved in the preparation and submission of the above manuscript.

Received: 27 August 2018 Accepted: 27 August 2018

Published online: 12 September 2018

\section{Reference}

1. Yang $X$, et al. HMGB1: a novel protein that induced platelets active and aggregation via Toll-like receptor-4, NF-KB and CGMP dependent mechanisms. BMC Diagn Pathol. 2015;10:134.

\footnotetext{
* Correspondence: hope058@163.com

'Depatment of Haematology, The Third Xiangya Hospital, Central South University, Changsha, Hunan, People's Republic of China

${ }^{2}$ Laboratory of Emergency Medicine, The Feinstein Institute for Medical Research, North Shore-LIJ Health System, Manhasset, NY 11030, USA

${ }^{3}$ Department of Hemotology Xiangya Hospital, Central South University,

Changsha, Hunan 410078, People's Republic of China
}

(c) The Author(s). 2018 Open Access This article is distributed under the terms of the Creative Commons Attribution 4.0 International License (http://creativecommons.org/licenses/by/4.0/), which permits unrestricted use, distribution, and reproduction in any medium, provided you give appropriate credit to the original author(s) and the source, provide a link to the Creative Commons license, and indicate if changes were made. The Creative Commons Public Domain Dedication waiver (http://creativecommons.org/publicdomain/zero/1.0/) applies to the data made available in this article, unless otherwise stated. 